\title{
Bal Ormanlarının Sosyo-Ekonomik Boyutunun İncelenmesi: Koyulhisar Örneği
}

\author{
Selda GEDİK ${ }^{1 *}$, Bektaş SÖNMEZ ${ }^{2}$, Samim KAYIKÇI ${ }^{3}$ \\ ${ }^{1}$ Sivas Cumhuriyet Üniversitesi, Koyulhisar Meslek Yüksekokulu, Ormancılık Bölümü, 58660, Sivas \\ ${ }^{2}$ Sivas Cumhuriyet Üniversitesi, Suşehri Timur Karabal Meslek Yüksekokulu, Gıda İşleme Bölümü, 5860, \\ Sivas \\ ${ }^{3}$ Hatay Büyükşehir Belediyesi, 31040, Antakya/Hatay, Türkiye
}

\section{Öz}

Arıcılık aktiviteleri biyolojik çeşitliliğin sürdürülmesi, erozyonun önlenmesi ve ekonomik gelir sağlaması açısından yürütülen önemli bir faaliyet alanıdır. Bu çalışmanın amacı, bal ormanlarından üretilen arı ve bal ürünlerinin sosyal çevreye ve bu ormanlarından sağlanan ürünlerin bölge ve ülke ekonomisi üzerine etkilerini araştırmaktır. Araştırma alanı Sivas İli Koyulhisar İlçesinde kurulan Ardıçalan ve Aydınlar Bal Ormanlarıdır. Anket çalışmasına dayalı olan bu çalışmada, katılımcılara kapalı uçlu soruları ve beşli likert tipi soruları içeren iki tip anket uygulanmıştır. Toplam 102 katılımcı anket çalışmasına katılmıştır. Anket sonucunda, arıcılığın ek gelir sağlamak için yapıldığı, daha çok çiftçiler tarafından sürdürüldüğü ve geleneksel yöntemler ile uygulandığı bulunmuştur. Ayrıca en çok üretilen arı ürünlerinin petek ve süzme bal olduğu tespit edilmiştir. En önemli anket sonucu ise yöre arıcılarının kurulan iki Bal Ormanının varlığından haberdar olmadığıdır. Arıcıların pazarlama ve bal ormanları konusunda bazı sorunlar yaşadığı gözlenmiştir. Pazarlama yapılan alanların uzak olması ve bal ormanı sayısının eksik olması yaşanan problemler arasındadır. Yeni pazar alanları oluşturulmalıdır. Bal ormanlarının sayısı artırılmalıdır. Mevcut bal ormanlarından daha fazla yarar sağlanabilmesi için bitki çeşitliliğinin devamının sağlanması, temiz su kaynaklarının oluşturulması ve arılara zarar veren yabanıl hayvanlara karşı tedbirler alınması önerilebilir.

Anahtar Kelimeler: Koyulhisar, bal ormanı, arıcılık, sosyo-ekonomik.

\section{Investigation of the Socio-Economic Scope of Honey Forests: The Koyulhisar Samples}

\begin{abstract}
Beekeeping activities are an important field of activity in terms of maintaining biological diversity, preventing erosion and providing economic income. The aim of this study is to investigate the effects of bee and honey products produced from honey forests on the social environment. Also, the products obtained from these honey forests on the economy of the region and country is aimed. The research area is Ardıçalan and Aydınlar Honey Forests established in Koyulhisar District of Sivas Province. In this study, which is based on a survey study, two types of surveys were applied to the participants, including closed-ended questions and five-point Likerttype questions. A total of 102 participants participated in the survey study. It has been found that beekeeping is done to provide additional income, is mostly maintained by farmers and is practiced with traditional methods. In addition, it has been determined that the most produced bee products are honeycomb and filtered honey. The most important result of the survey is that the local beekeepers are not aware of the existence of two Honey Forests. It has been observed that beekeepers have some problems in marketing and honey forests. The remoteness of the marketing areas and the lack of honey forests are among the problems experienced. New market areas should be created. The number of honey forests should be increased. In order to get more benefits from the existing honey forests, it can be suggested to maintain plant diversity, create clean water sources and take measures against wild animals that harm bees.
\end{abstract}

Keywords: Koyulhisar, honey forest, honey beekeeping, socio-economic. 


\section{Giriş}

Türkiye'de ormanlar ile çevrelenmiş alan azımsanmayacak kadar büyüktür. Fakat bu kuşatılmış alanın önemli bir bölümü bozuk vasıflı statüdedir. Bu bağlamda verimsiz orman sahalarının yeniden kazandırılmasına ihtiyaç vardır. Bal ormanlarının bu sahalarda kurulması ise yapılacak en önemli girişimlerden birini oluşturmaktadır (BOEP, 2013).

Bal ormanı yerinin ve alanlarının belirlenmesinde bazı kriterler ön plana çıkmaktadır. Bal ormanları, rüzgârın en az hissedildiği, trafik hareketliliğinin yoğun olduğu bölgelere en az 200 metre ve stabilize ara yollara en az 30 metre uzaklıkta kurulabilir. İnsan ve hayvanlardan uzak, temiz su kaynağına yakın, arıcılık ve arı ürünlerine olan talebin fazla olduğu alanlar seçilmektedir. Son olarak belirlenen alanın en az 20 hektarlık (ha) bir alan olmasina gereksinim duyulmaktadır (BOEP, 2013).

Arıcılık, maliyeti düşük, toprağa bağımlılığın az olduğu ve kısa sürede gelir sağlayan bir iş koludur (Koday, 2005). Arıcı ise zamanının önemli bir bölümünü ya da tamamını arıcılığa ayırarak kendisine maddi kazanç sağlayan, dolayısıyla bu işi meslek edinmiş kişidir (Arıcılık Yönetmeliğii, 2011). Orman sahaları arıcılığın yapıldığı ve arıcılık faaliyetlerinin sürdürüldüğü alanlar olarak karşımıza çıkmaktadır. Üstelik ekonomik olarak sağladığı kazanca bağlı olarak insanlar için gelir kaynağı olmaktadır (Koday, 2005). Bitki çeşitliliği açısından oldukça zengin olan Türkiye'de bal üretimi son yıllarda önemli bir ivme kazanmıştır (Gül, 2008). Son zamanlarda sağlık açısından da önemli bir yere sahip olduğu anlaşılan bal üretimi, arıcılığa olan ilgiyi de artırmıştır. Ayrıca arıcılık denilince sadece bal üretimi değil bunun yanında arı sütü, arı zehri, propolis, polen, bal mumu gibi ürünlerin üretimi de sağlanmaktadır. Türkiye’de birçok bölgede bu ürünlerin varlığı bilinmemektedir. Tüm bunlara ek olarak pek çok ülkede "Arı Ürünleri ile Tedavi" anlamına gelen "Apiterapi" de başka bir arıcılık ve arı ürünleri ile ilgili bir alandır (Krell, 1996). Çin, Japonya, Yeni Zelanda, Polonya, Macaristan gibi birçok ülkede arı ürünlerinin beslenme amaçlı tüketiminin dışında çeşitli hastalıkların tedavisinde ve iyileştirilmesinde yararlanılmakta; ilaç, gıda, kozmetik ve içki endüstrilerinde yaygın olarak kullanılmakta, bu konuda her biri ayrı bir sektör oluşturarak her geçen gün artan bir hızla gelişme potansiyeli göstermektedir (Krell, 1996).

Kovan sayısı üzerinde durulması gereken konulardan biridir. Dünya'daki kovan sayısına bakıldığında 91 milyon civarında olduğu tespit edilmiştir (TÜP, 2020). Ülkemizde kovan sayısının en fazla olduğu iller arasında Muğla, Sivas, Ordu ve Adana yer almaktadır. Bal üretiminde ise Ordu, Muğla, Adana ve Sivas olarak sıralanmaktadır (TÜIK, 2020). Ülkemiz de bugün itibariyle arıcılık yapan işletme sayısı 80.675 (adet), toplam kovan sayısı 8.128.360, bal üretimi 109.330 (ton), balmumu üretimi 3.971 (ton) ile önemli bir arıcılık potansiyeli göstermektedir. Bal üretimi ile bir yandan ülke ihtiyaçları karşılanırken bir yandan da Almanya, Suudi Arabistan, ABD ve Avusturya'ya ihracatı yapılabilmektedir. Balmumu Adana, Sivas ve Muğla illerinde üretimi yapılan bir üründür. Balmumu'nun metal, kozmetik ve tekstil alanlarında değerlendirilmesi; ilaç ve mum yapımında da kullanılması ürüne olan talebi artırmıştır (TÜP, 2020).

Arıcılık faaliyetinin ormanlık alanlarda etkin olarak sürdürülmesinin ekolojik, sosyal ve ekonomik yaşam üzerinde önemli bir etkisi bulunmaktadır. Bunlar içerisinde erozyon önleme, biyolojik çeşitliliğin devamını sağlamak, bölge ve yöre insanlarının ekonomisini iyileştirmek ve ülke ekonomisine mali kazanç sağlamak yer alır. Yine bu faaliyetin orman kaynaklarının koruma ve kullanma ilkesi doğrultusunda modern bir anlayış ile planlama sürecine eklenmesi önemli görülmektedir. Mevcut ormanlar korunarak, 1slah edilerek, ağaçlandırma yaparak ve bölgenin iklimine uygun bir bitki örtüsü kazandırılarak bal ormanları kurulabilmektedir (Koday ve Karadağ, 2019). Bu şekilde yeni kurulacak ve/veya kurulmuş olan bal ormanlarının arıcılar tarafından kullanılmasının bölge ve ülke ekonomisine katkısı kaçınılmaz olacaktır. Ancak kurulacak ve/veya kurulmuş olan bal ormanlarının etkin bir şekilde kullanılması bölge ve yöre insanlarının ekonomisini iyileştirmek ve ülke ekonomisine mali kazanç sağlamak için önemlidir. Bu çerçevede, bu çalışmanın amacı; bal ormanlarından elde edilen arı ve bal ürünlerinin sosyal çevreye etkilerini incelemek ve bal ormanlarından sağlanan ürünlerin bölge ve ülke ekonomisi üzerindeki durumunu belirlemektir.

\section{Materyal ve Metot}

\subsection{Materyal}

Araştırma sahası olarak Tarım ve Orman Bakanlığı, Giresun Orman Bölge Müdürlüğü, Koyulhisar Orman İşletme Müdürlüğü, Iğdırdağ Orman İşletme Şefliği kontrolündeki Ardıçalan Bal Ormanı ve Karaçam Orman İşletme Şefliği yönetimindeki Aydınlar Bal Ormanı göz önünde bulundurulmuştur. Her iki bal ormanı Sivas İli 
Koyulhisar İlçesi’nde yer almaktadır. Bu iki bal ormanının toplam alanı yaklaşık 172 hektardır. Ardıçalan Bal Ormanı (40 19’ 56.88” K, $37^{\circ}$ 45’ 41.76” D), Kalebaşı Köyü’nden 3,5 km uzaklıkta ve kuzeybatı da yer alır. Rakımı 1500-1750 metre aralığında, yer yer engebeli ve güney bakıda bulunmaktadır. Ayrıca 114,115 ve 116 numaralı bölmelerden oluşmakta ve 85.0 hektarlık (Ha) bir alanı kuşatmaktadır. Aydınlar Bal Ormanı (40 $11^{\circ}$ ' 43.25” K, 37 59’ 53.24” D) Aydınlar Köyü’nün 800-1000 metre doğusunda olmasının yanı sıra ilgili şefliğin amenajmanın 78 numaralı bölmesi içinde ve 87.0 hektarlık (Ha) bir alanı kuşatır. Yeryüzü yapısı engebeli olup, ortalama \%21-60 eğimlidir. Proje sahasının en yüksek noktası 1.290 m. olup, ortalama yükseklik 1.0001.100 m. civarındadır (Şekil 1).

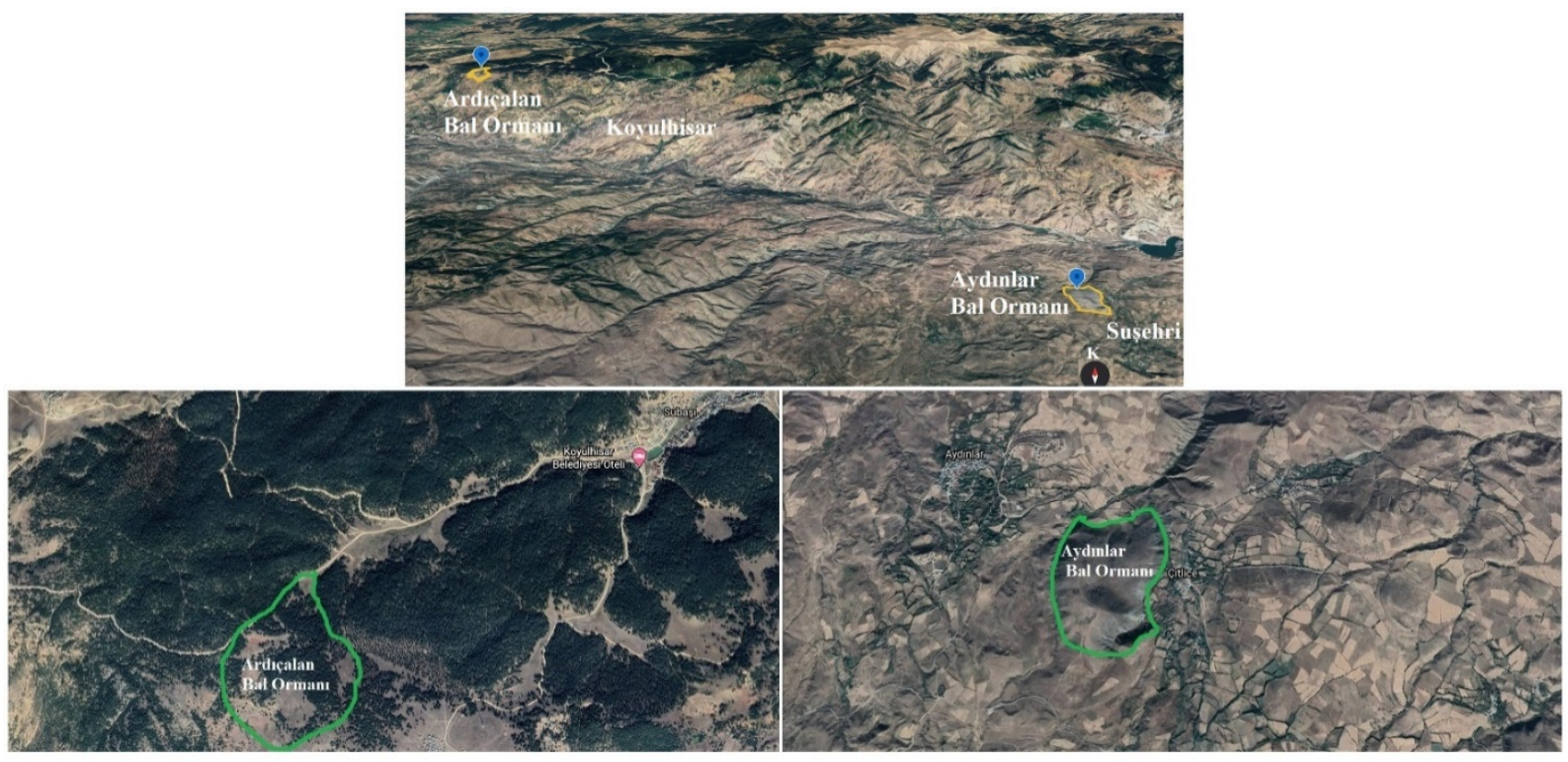

Şekil 1. Ardıçalan ve Aydınlar bal ormanlarının genel görünümü.

\subsection{Metot}

2016 yılında Sivas İli Koyulhisar İlçesi’nde ikamet eden ve arıcılık faaliyetini meslek edinmiş bireylerle ilgili olarak yüz yüze görüşme ile iki tip anket gerçekleştirilmiştir. Toplam 112 birey ile anket çalışması yapılmış, 10 bireyin sorulara olan yaklaşımının samimi olmaması ve tüm soruların aynı seçenek ile cevaplandırılmasına bağlı olarak bu bireylere ait anket verileri çalışmanın dışında tutulmuştur.

İki tip anket hazırlanmıştır. İlkinde kapalı uçlu sorular bulunmakta, deneğin kendisine uygun bulduğu tercihi seçenekler arasından seçmesi istenmiştir (Karasar, 2003) (EK 1). İlk ankette soru sayısı 15'dir. İkinci anket tipinde standart sorular olmakla birlikte, sorular cümle yapısı bozulmadan ve aynı sıraya göre katılımcılara sorulmuştur (beşli likert tipi sorular). Buradaki amaç denekler üzerinde zihin karışıklığına yol açmamaktır. Böylelikle soruların aynı düzeyde anlaşılması, yorumlanması ve kendi düşüncesine göre ifade edilmesi sağlanmıştır (Ekiz, 2003) (EK 2). İkinci ankette soru sayısı 11'dir. Bu ankette seçenekler olumsuzdan olumluya doğru sıralanmış (hiçbir zaman, nadiren, bazen, genellikle, her zaman) ve 1-5 arasında puanlanmıştır.

Kapalı uçlu sorulara ilişkin elde edilen bulgular yüzdesel olarak hesaplanmış, en yüksek ve en düşük değerler belirlenmiştir. Standart soruları içeren diğer ankete dair veriler Ana (Temel) Bileşenler Analizi (ABA) ile değerlendirilmiştir. ABA, değişkenlerin varyans yapısını daha az sayıda ve bu değişkenlerin doğrusal bileşenleri olan yeni değişkenler ile ifade etme yöntemidir. Verilerin çoklu normal dağılım gösterip göstermediği Barlett testi, verilerin örneklem büyüklüğü yeterliliği ise Kaiser-Meyer-Olkin testi ile değerlendirilmiştir. İstatistiksel testler için SPSS 17.0 paket programı kullanılmıştır.

\section{Bulgular ve Tartışma}

Anket çalışmasında toplam 102 katılımcı yer almış ve bu katılımcıların bazı sosyo-demografik özelliklerine yönelik bulgular Tablo 1'de verilmiştir. Katılımcıların yaş dağılımı analiz edildiğinde, \%14,7'sinin 20-30, \%28,4'ünün 31-40, \%25,5'inin 50-51 yaş aralığında ve \%31,4'ünün ise 51 yaş ve üzeri bireylerle temsil edildiği görülmektedir. Katılımcılar eğitim düzeyleri açısından sınıflandırıldığında, \%58,9'u ilköğretim, 
\%29,4’ü lise ve geriye kalanı ise ön lisans mezunudur. Ayrıca katılımcılar mesleklerine göre sınıflandırıldığında \%53'ünün çiftçi, \%39,2'sinin işçi/memur, \%6,8'inin herhangi bir geliri olmayan ve \%1'inin ise orman işçisi olduğu görülmektedir.

Kapalı uçlu soruların yer aldığı birinci tip anket sonuçları aşağıda sıralanmaktadır: Veriler en yüksek ve en düşük oranlara göre aktarılmıştır.

Anketin ilk sorusuna, “Arıcılıktan yıllık üretim miktarınız ne kadar?”, \%26'sı 50-100 kg, \%17’si 250-500 kg ve \%17'si 500-1000 kg seçeneğini işaretlemiştir. Anketin ikinci sorusuna, “Arılarınıza zarar veren hayvanlar nelerdir?”, \%42'si ayı-domuz, \%4’ü ise fare-sıçan-kurbağa seçeneğini işaretlemiştir. Anketin üçüncü sorusuna, “Arıcılığı hangi amaçla yapıyorsunuz?”, \%54'ü yan gelir amaçlı, \%9'u ise ekonomik-hobi amaçlı seçeneklerini işaretlemiştir. Anketin dördüncü sorusuna, "Kaç tane kovan sayınız bulunmaktadır?”, \%38,4'ü 1-25 kovan \%10’u ise 50-75 kovan seçeneğini işaretlemiştir. Anketin beşinci sorusuna, "Bal üretimi hariç hangi arıcılık ürünleri üretiyorsunuz?”, \%42’si petek bal, \%14'ü ise bal mumu üretimini tercih etmiştir.

Tablo 1. Katılımcıların bazı sosyo-demografik özellikleri.

\begin{tabular}{llll}
\hline Özellikler & Gruplar & $\mathbf{n}$ & $\mathbf{( \% )}$ \\
\hline Cinsiyet & Kadın & 0 & 0 \\
& Erkek & 102 & 100 \\
Yaş & $20-30$ & 15 & 14,7 \\
& $31-40$ & 29 & 28,4 \\
& $41-50$ & 26 & 25,5 \\
Ĕgitim & $51>$ & 32 & 31,4 \\
& İlköğretim & 60 & 58,9 \\
\multirow{3}{*}{ Meslek } & Lise & 30 & 29,4 \\
& Üniversite & 12 & 11,7 \\
& Çiftçi & 54 & 53,0 \\
& İşçi/Memur & 40 & 39,2 \\
& Geliri yok & 7 & 6,8 \\
& Orman İşçisi & 1 & 1,0 \\
\hline
\end{tabular}

Anketin altıncı sorusuna, “Arıcılık ile ilgili problemleriniz neler?”, \%40 pazarlama, \%7'si ise diğer problemler yanıtını seçmiştir. Anketin yedinci sorusuna, “Ürününüzü pazarladığınız kesimi nereler oluşturuyor?”, \%30’u büyük şehirler, \%3'ü ise diğer pazarlama alanları olarak yanıtlamıştır. İstanbul pazarlamanın en fazla yapıldı $\breve{g}_{1}$ il olarak karşımıza çıkmaktadır. Anketin sekizinci sorusuna, "Arıcılık dışında bir mesleğiniz (yan geliriniz) var mı?", \%53'ü çiftçi, \%1'i ise ormancılık olarak tercihte bulunmuşlardır. Anketin dokuzuncu sorusuna, "Kovan konaklama yerleriniz nerelerdir?", \%43’ü yakın çevreleri, \%4'ü ise arıların konaklaması için bal ormanlarından yana bir tercih yapmışlardır. Anketin onuncu sorusuna, “Arıcılıkla ilgili hangi eğitimi aldınız?”, \%49'u eğitim almadım, \%7’si ise eğitim almayı düşünüyorum yanıtını vermişlerdir.

Anketin on birinci sorusuna, “Kaç yıldır arıcılık yapıyorsunuz?”, \%27'si 7 ve üzeri, \%13'ü ise 5-7 yıldır arıcılık yapmaktayım olarak işaretleme yapmıştır. Anketin on ikinci sorusuna, "Ana arıyı nereden temin ediyorsunuz?”, \%41'i kendi üretimim, \%1'i ise diğer üreticilerden ana arıyı temin ediyoruz cevabını vermiştir. Anketin on üçüncü sorusuna, “Arıcılıkta hangi arı ırkını tercih ediyorsunuz?”, \%40’1 Kafkas+Karniyol melezi, $\% 10$ ' $\mathrm{u}$ ise belirtilen arı ırklarını bilmediklerini ve kullandıkları arı cinsini tanımadıkları cevabını vermiștir. Anketin on dördüncü sorusuna, “Arıların bakımını kim yapıyor?”, \%74'ü kendim, \%2'si ise komşumuz olarak yanıtlanmıştır. Anketin son sorusuna, "Arıcılık ve bal üretimi ile ilgili gerekli bilgiyi hangi kaynaklardan temin ediyorsunuz?”, \%60’1 yakın çevre ve geleneksel yöntemlerin ağırlıkta olduğunu, \%5'i ise dergilerden öğrendiklerini belirtmektedirler.

Standart soruların yer aldığı beşli likert tipi soruları içeren ankette 11 soru bulunmakta ve soruların her biri bir sınıflamaya, diğer bir ifadeyle de olumsuzdan olumluya doğru dizinlenmiştir. Veriler ABA ile değerlendirilmiştir. Sorulara verilen yanıtların oransal karşılığı Tablo 2'de özetlenmiştir. 
Tablo 2. Ankete katılan kişilerin cevaplarının oransal dağılımı (\%) (yüksek oranlar koyu renk ile gösterilmiştir).

\begin{tabular}{llllllllllll}
\hline Tercihler & \multicolumn{1}{c}{ Soruların tercihlere göre oransal dağılımı } \\
\cline { 2 - 11 } & 1 & 2 & 3 & 4 & 5 & 6 & 7 & 8 & 9 & 10 & 11 \\
\hline Hiçbir Zaman & 13,1 & 10,1 & 12,2 & 5,1 & 20,4 & 9,3 & $\mathbf{3 6 , 1}$ & $\mathbf{4 8 , 5}$ & 17,2 & 5,1 & $\mathbf{4 5 , 5}$ \\
Nadiren & 7,1 & 15,2 & 17,3 & 20,4 & $\mathbf{2 8 , 6}$ & 8,2 & 27,8 & 13,1 & 14,1 & 10,1 & 26,3 \\
Bazen & 11,1 & $\mathbf{2 5 , 3}$ & 22,4 & 23,5 & 18,4 & 14,4 & 29,9 & 12,1 & $\mathbf{2 5 , 3}$ & 17,2 & 12,1 \\
Genellikle & 28,3 & $\mathbf{2 5 , 3}$ & 18,4 & 21,4 & 14,3 & $\mathbf{4 3 , 3}$ & 5,2 & 10,1 & $\mathbf{2 5 , 3}$ & 27,3 & 8,1 \\
Her zaman & $\mathbf{4 0 , 4}$ & 24,2 & $\mathbf{2 9 , 6}$ & $\mathbf{2 9 , 6}$ & 18,4 & 24,7 & 1,0 & 16,2 & 18,2 & $\mathbf{4 0 , 4}$ & 8,1 \\
Toplam & 100 & 100 & 100 & 100 & 100 & 100 & 100 & 100 & 100 & 100 & 100 \\
\hline
\end{tabular}

İkinci tip anketteki bazı sorular ve sorulara verilen yanıtlardan bir bölümü şu şekildedir: Anketin ikinci sorusunda, "Ürünümün pazarlandığ 1 yeri bilirim.”, \%25,3 ile "bazen” ve \%25,3 ile de "genellikle” seçeneği ön plan tutulmuştur. Burada bir konuya vurgu yapmak gerekmektedir. "hiçbir zaman” ve "nadiren” cevaplarını verenler ile birlikte arıcılık faaliyetleriyle uğraşanlar daha çok bu konu da olumsuz bir tutum sergilemektedirler. Anketin beşinci sorusuna, "Devletin oluşturduğu bal ormanlarını tercih ederim.”, ağırlıklı olarak \%28,6 ile "nadiren” ve \%20,4 ile de "hiçbir zaman” tercihi yapılmıştır. Bu sonuç arıcılık faaliyetinde bulunan insanların bal ormanlarına olumlu bakmadıkları şeklinde yorumlanabilir. Anketin sekizinci "Arıcılık için devletten destek alırım" ve on birinci "Arıcılık için devletten destek alıyor musunuz? (Teşvik, Kredi)" soruları benzerlik gösterir ve katılımcıların önemli bir bölümü (sırasıyla \%48,5 ve \%45,5) "hiçbir zaman" seçeneğini işaretlemişlerdir. Bu ise Sivas İli Koyulhisar İlçesi'nde arıcılık ile uğraşanların ürününü pazarlama konusunda sorun yaşadı̆̆ını, ilgili kurumlardan bal ormanlarının kullanımı açısından, teşvik ve kredi gibi destek hizmetlerinden faydalanmadığını düşündürmektedir.

ABA sonucunda 11 ana bileşen elde edilmiştir. Ancak 3. ana bileşen altındaki varyansı çok düşük olan ve normal dağılım göstermeyen 7. ve 4. sorular testten çıkarılmış ve veriler tekrar ABA' ya tabi tutulmuştur. Veri setinin çoklu normal dağ 1 lım gösterip göstermediği Barlett testi ile test edilmiş ve bu test sonucunda da verilerin çoklu normal dağılım gösterdiği anlaşılmıştır (Khi-kare=303,119; df=36; $\mathrm{P}=0,001$ ). Verilerin örneklem büyüklüğü yeterliliği testi Kaiser-Meyer-Olkin testi ile ölçülmüş ve bu test sonucunda değer 0,808 olarak hesaplanmıştır. Bu değer örneklem büyüklüğünün iyi derecede olduğunu göstermektedir.

ABA sonucu, toplam 9 ana bileşen üretilmiş ve ana bileşenlerin sahip olduğu varyasyon yüzdeleri Tablo 3'de gösterilmiştir. Bu sonuçlara göre toplam varyansın \%44,5’i birinci ana bileşende (AB1), \%11,4’ü ikinci ana bileşende (AB2) toplanmıştır. Böylece ilk iki ana bileşen, toplam varyansı tek başına \%55,9 oranında açıklamıştır.

Tablo 3. ABA sonucu varyanslarının Ana Bileşenlere (AB) dağılımı.

\begin{tabular}{llll}
\hline Ana Bileşenler & Toplam Varyans & Varyans (\%) & Genel Toplam (\%) \\
\hline AB 1 & 4,005 & 44,499 & 44,499 \\
AB 2 & 1,027 & 11,414 & 55,913 \\
AB 3 & 0,982 & 10,912 & 66,826 \\
AB 4 & 0,814 & 9,041 & 75,867 \\
AB 5 & 0,688 & 7,646 & 83,513 \\
AB 6 & 0,508 & 5,646 & 89,158 \\
AB 7 & 0,400 & 4,447 & 93,606 \\
AB 8 & 0,329 & 3,660 & 97,266 \\
AB 9 & 0,246 & 2,734 & 100,000 \\
\hline
\end{tabular}

ABA sonucu değişkenlerin rotasyona tabii tutulduktan sonra Ana Bileşenler altındaki değerleri Tablo 4'te gösterilmiştir. Buna göre 8., 11., 2. ve 5. sorular birinci ana bileşen (AB1) altında toplanırken, diğerleri (6., 9., 10., 3., ve 1. sorular)) ikinci ana bileşen (AB2) altında toplanmıştırlar. AB1 altında toplanan soruların, Sivas İli 
Koyulhisar İlçesi arıcılık faaliyetleri ve sosyo-ekonomik boyutu açısından diğer sorulara göre daha belirleyici olduğu anlaşılmaktadır.

Tablo 4. Değişkenlerin rotasyona tabii tutulduktan sonra ana bileşenler altındaki değerleri.

\begin{tabular}{lll}
\hline & AB 1 & AB 2 \\
\hline Soru 8 & $\mathbf{0 , 8 7 4}$ & 0,200 \\
Soru 11 & $\mathbf{0 , 7 8 0}$ & 0,200 \\
Soru 2 & $\mathbf{0 , 6 2 3}$ & 0,292 \\
Soru 5 & $\mathbf{0 , 4 7 3}$ & 0,125 \\
Soru 6 & 0,060 & $\mathbf{0 , 8 1 6}$ \\
Soru 9 & 0,197 & $\mathbf{0 , 7 8 8}$ \\
Soru 10 & 0,421 & $\mathbf{0 , 6 2 0}$ \\
Soru 3 & 0,340 & $\mathbf{0 , 5 9 6}$ \\
Soru 1 & 0,458 & $\mathbf{0 , 5 4 5}$ \\
\hline
\end{tabular}

ABA sonucu, soruların vektörel görünümü Şekil 2'de gösterilmiştir. Şekil 2'den anlaşılacağ1 üzere 8., 2 ., 11. ve 5. sorular merkezden aynı noktaya doğru kümelenmiş, 8. ve 11. sorular ise en uzak noktada yer almıştır. ABA sonucu elde edilen bilgiler şekilsel olarak vektörel dağılım ile desteklenmiştir.

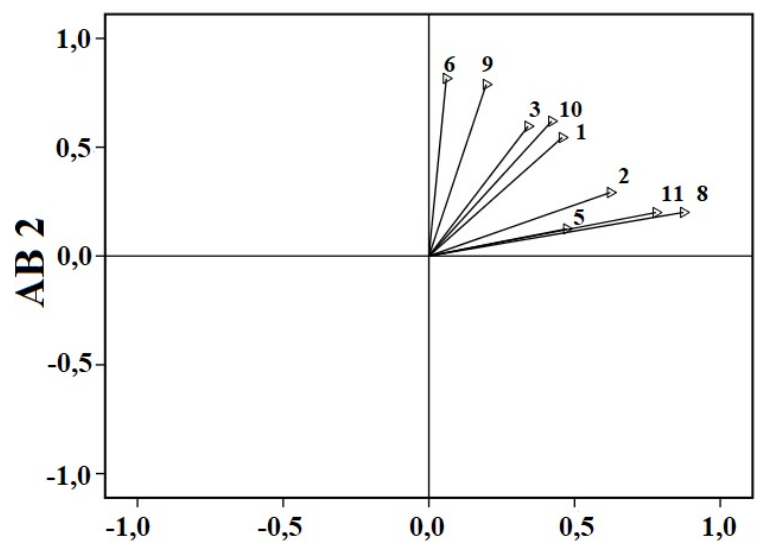

AB 1

Şekil 2. Ana bileşenler analizi sonucu verilerin vektörel dağılımı.

Bir bölgenin dünya üzerindeki konumu arıcılık faaliyetini etkileyebilir. Örneğin Antalya İli’nin Akdeniz iklimi etkisi altında olması, arıcılık faaliyetinin erken başlamasına ve erken bal üretimine neden olmaktadır. Antalya İli’nde yerli ve yabancı turistlerin ziyareti bölgede bal ve arı ürünleri üretimi ve pazarlaması konusunda girişimleri artırmıştır. İlde valilik tarafından bal eylem planı hazırlanarak uygulamaya geçirilmiştir (BOEP, 2004). Bölgenin ılıman bir iklime sahip olması ve narenciye çiçeklerinin varlığı erken bal üretimini mümkün kılmaktadır. Sivas ilinin Koyulhisar bölgesi ise Karadeniz ikliminin ve karasal iklimin beraber gerçekleştiği ve yükseklik farkının bulunduğu bir yerdir (Karadeniz, 2010). Bu nedenle bölgede arıcılık faaliyetlerine geç başlanmaktadır. Arıcılık, Koyulhisar bölgesinde yan gelir olarak yapılmakta, fazla iş kolu olmayan bölge için yeni bir iş sahası oluşturmaktadır. Öyle ki, herhangi bir yan geliri olmayan meslek grubunun çok düşük oranda $(\% 6,8)$ olması, katılımcıların ikinci bir işe sahip olduğunu ve ev ekonomisine katkıda bulunmak amacıyla arıcılık faaliyetlerini yaptıkları fikrini ortaya çıkarmaktadır. Benzer durum Muğla ili geneli için de bulunmuştur (Akyol ve Cazağ, 2018). Anket çalışmasına katılanlarının tamamı erkek bireylerden oluşmaktadır, bu durum bölgede arıcılık faaliyetlerine kadınların ilgisinin olmadığını göstermektedir. Benzer şekilde kadınlar arasında arıcılık faaliyetlerine ilginin az olduğu daha önce ki çalışmalarda da ortaya konmuştur (Akyol ve Cazağ, 2018).

Arıcılık faaliyetleri hakkında çeşitli kurumlar tarafından eğitimler verilmektedir. Bingöl İli’nde gerçekleştirilen birkaç proje ile arıcılık, ana arı ve organik bal üretimi, arı yetiştiriciliği, dolum ve ambalajlama konularında kadınlara eğitim verilmiştir. Ayrıca bölgede bal paketleme ve dolum tesisi kurulmuştur (Pirim vd., 2009). Koyulhisar ilçesinde talep olduğu takdirde Halk Eğitim Müdürlüğü tarafından sertifikalı arıcılık kurs 
programları düzenlenmektedir. Arıcılığın ülke ekonomisine katkısını artırmak için bölgede Bal Ormanları kurmasının yanında diğer kurumların da dahil olduğu projeler vasıtasıyla arıcılık teşvik edilmelidir. Önal ve Bekiroğlu (2011)’a göre orman köylerinde ORKÖY tarafından gerçekleştirilen projelerden birini arıcılık oluşturmaktadır. Bu kapsamda ORKÖY, orman köylerinin kalkındırılması için arıcılık ve kovan destekleri sağlamaktadır. Burada ki amaç orman köylerinde yaşayan insanların ve bölgenin kalkınmasına katkı sağlamaktır. Bölgede yaşayan insanların geçmişi de arıcılık faaliyetlerine dayanmaktadır. Bu nedenle arıcılık hususundaki proje sayısının artırılarak orman köylülerine sosyal ve ekonomik katkı sağlanmış olacaktır.

Yapılan bir çalışmada Muğla ili ve çevresinde arıcılığın kadın-erkek, genç-yaşlı ayrımı olmadan farklı yaş gruplarından herkesin yapabileceği, tarım veya ormancılık gibi toprağa bağımlı olmayan bir iş kolu olması sebebiyle, tercih edilebildiği sonucuna ulaşılmıştır. Yine arıcılığın gelişmesi için sahada aktif teknik elemanların sayısının arttırılması gerekmektedir. Arıcılıkla elde edilen ürünlerini işleyip diğer sanayi kollarına kazandıracak kozmetik, ilaç sanayi vb. alanlarda kullanılabilecek bir sektör oluşturulmalıdır. Bu da yeni iş sahaları oluşturabilecektir. Böylece arı ürünlerinin katma değeri arttırılarak arıcılık sektörüne önemli katkılar sağlanacaktır (Akyol ve Cazağ, 2018). Bu durum Koyulhisar yöresi içinde geçerli olup yöre için yeni iş kolları yaratılabilir.

Bir bölgenin bitki çeşitliliği de bal verimini etkilemektedir. Bitki çeşitliliği ile bölgenin bal üretim miktarı artmakta veya azaltmaktadır. Yine çiçekli bitki sayısının varlığı, bal verimi artışını mümkün kılmaktadır. Bartın yöresine yönelik yapılan bir çalışmada kestane, ıhlamur ve yalancı akasya ağaçlarının varlığına dayanarak, bal üretiminin yapılması ile ekonomik değerin arttırılabileceği belirtilmiştir (Güngör ve Ayhan, 2016). Son yıllarda ülkemiz bal verimini arttırmaya yönelik olarak Orman Genel Müdürlüğü'nce gerçekleştirilen ağaçlandırma çalışmalarında, kestane ve ıhlamur ağaçlarına önem verilmektedir. Diğger yandan Güngör ve Ayhan (2016), potansiyel bal ormanı alanlarının belirlenmesi ve bu alanların üzerinde arıcılık faaliyetinin yapılması halinde ekonomiye getirecek yıllık gelirin artacağını tespit etmiştir. Araştırma konusu olan Koyulhisar Bal Ormanları'nda yalancı akasya ve mera bitkilerinin kullanılması, arıcıların bal üretimini arttırmaya yönelik bir faaliyetin parçasıdır. Ayrıca Koyulhisar yöresinde bozuk orman alanlarının da bu şekilde değerlendirilmesi yoluna gidilerek bal üretimini artırmak mümkündür.

İlçe de 2015 yılı için toplam 253 işletme sayısı üzerinden, 16.960 modern kovandan $305.000 \mathrm{~kg}$ bal ve 21.000 kg bal mumu elde edilmiştir (Koyulhisar İlçe Tarım Müdürlüğü, 2015). Bingöl'de yapılan bir araştırmada ise ortalama kovan sayısı 133.6 adet tespit edilmiş buna rağmen bal verimi ise ortalama 11,1 kg'da kaldığı anlaşılmıştır (Söğüt vd., 2019). Bu sonuçlara göre Koyulhisar'da kovan sayısı ortalaması düşük olmasına rağmen kovanlardan alınan bal verimi daha yüksektir. Bu da ilçenin arı ürünleri üretim potansiyelinin ve kovan sayısının artırılarak ekonomik gelirin artırılacağını göstermektedir.

Iğdır İli’nde arıcılarının sosyo-ekonomik durumu üzerine yapılan bir çalışmaya göre arıcıların pazarlama ile ilgili sorun yaşadığı belirlenmiştir (Kadirhanoğulları vd., 2016). İlgili çalışmada, arı ürünlerinin pazarlanması ile ilgili kooperatifin bulunmaması, arı ürünlerinin hak edildiği değere satılmaması, fiyat standardının bulunmaması arıcılığın ana sorunları olarak belirtilmiştir. Malatya'da yapılan bir başka araştırmada (Köseman vd., 2016) ise, bal dışındaki diğer arı ürünlerine yönelik pazarın gelişmemesi ikinci önemli sorun olarak tespit edilmiştir. Koyulhisar yöresinde de benzer pazarlama sorunları bulunmaktadır. Aslında ilçede Tarım kooperatifin bulunması bölgenin artısı olarak görülmektedir. Buna rağmen pazarlama sorunu, bölge arıcılığı için çözülmesi gereken önemli bir sorun olarak karşımıza çıkmaktadır.

Dünya genelinde 59 milyon civarında arı kovanı bulunmakta ve 1 milyon 250 bin ton bal üretilmektedir. Dünyada kovan sayısı en fazla olan ülke 12 milyon ile Hindistan olmasına karşın 9 milyon arı kovanına sahip Çin, 543 bin ton ile en çok bal üreten ülke konumundadır (Güngör ve Ayhan, 2016). Çin’i 115 bin ton ile Türkiye, 76 bin ton ile Arjantin izlemektedir (FAO, 2017). Bu veriler doğrultusunda dünyadaki en önemli ikinci bal üreticisinin Türkiye olduğu ifade edilebilir. Böylece ülke genelinde sayısı giderek artan Bal Ormanları, kuruldukları bölgeye hem ekonomik olarak katkı sağlamakta hem de sürdürülebilir ormancılığı ve ülke ekonomisini desteklemektedir (Koday ve Karadağ, 2019).

Dünya'da ortalama bal üretimi 22 kg/kovan'dır. Ortalamanın üzerinde bal üretimi yapılan ülkeler arasında Kanada (56 kg/kovan), Çin (52 kg/kovan), Meksika (39 kg/kovan), Arjantin (27 kg/kovan) ve ABD (26 $\mathrm{kg} /$ kovan) yer almaktadır. Kovan başına en az bal üretimi ise 4 kg/kovan ile Hindistan'dır (FAO, 2015). 12. sırada yer alan Türkiye'de $15 \mathrm{~kg} /$ kovan üretimi ile dünya ortalamasının gerisinde kalmıştır ve bu sonuç kovan sayısı ve bal üretimi ile uyuşmamaktadır (Güngör ve Ayhan, 2016). Koyulhisar İlçesi'nde üretilen bal miktarı $18,5 \mathrm{~kg} /$ kovandır. Bu değer dünya ortalamasının altında $(22 \mathrm{~kg} / \mathrm{kovan})$, Türkiye ortalamasının (15 kg/kovan) ise üstündedir. Yine bu değer, yörede kovan başına üretilen bal miktarının il bazında üretilen bal 
miktarlarından fazla olduğunu göstermektedir. Hatta Karadeniz Bölgesi bal miktarının 17 kg/kovan olduğu düşünüldüğünde Koyulhisar'dan elde edilen değerlerin daha iyi olduğu ifade edilebilir. Bu iyimser tablonun oluşmasında Koyulhisar İlçesi’nin iklimi, bitki örtüsü, geçiş zonunda olması, yaylacılık faaliyetleri için elverişli olması ve iki bal ormanına sahip olmasının etkili olduğu gözlenmiştir. 2014 yılında ilçe sınırları içinde toplam 14.469 adet modern kovan bulunmaktadır. Toplam $274.911 \mathrm{~kg}$ bal ve $18.810 \mathrm{~kg}$ bal mumu üretimi gerçekleşmiş̧ir (Koyulhisar İlçe Tarım, 2015).

\section{Sonuç ve Öneriler}

Koyulhisar İlçesi'nde gerçekleştirilen anket çalışmasından elde edilen sonuçlar kısaca aşağıdaki gibidir. Üretilen yıllık bal üretimi üretici bazında kovan başına 0-25 kg aralığında ve ortalama kovan sayısı ise 25 'dir. Pazarlama arıcıllk faaliyeti için en önemli sorunu oluştururken üretilen ürünler büyükşehirlere pazarlanmaktadır. Yörede arıcılık ek gelir sağlamak için yapılmakta, daha çok çiftçiler tarafından sürdürülmekte ve geleneksel yöntemler uygulanmaktadır. Arıcılar ortalama yedi yıl ve üzeri bir sürede bu işle uğraşmakta ve bakım işlerini kendi olanakları ile yapmaktadır. Üretilen arı ürünleri arasında petek ve süzme bal yer alır. Anket sonuçları, yöre insanlarının kurulan iki Bal Ormanının varlığından haberdar olmadığını göstermektedir.

Türkiye'de iklim, bitki örtüsü, toprak, su kaynakları ve benzeri açıdan gözlenen zenginliğin arıcıllı için uygun bir zemin hazırlaması, üretilen balların kaliteli olması ve sosyo-ekonomik kalkındırmayı hızlandırması arıcılık faaliyetinin gelişimine katkı sağlayacaktır (Koday ve Karadağ, 2019). Koyulhisar İlçesi’nde kurulan Ardıçalan ve Aydınlar Bal Ormanları, bal ormanı kurulması için gerekli olan kriterlerin çoğunu sağlamaktadır. Bu da verimlilik açısından bir artışın olması ve bölge ihtiyaçlarının karşılanması açısından bu iki bal ormanı önemli bir potansiyel olduğunu göstermektedir.

Dünyada İklim değişikliğinin etki alanı giderek artmakta, iklimler, bitki örtüsü ve canlılar bu durumdan olumsuz etkilenmektedir. Öyle ki birçoğu yok olma tehlikesiyle yüz yüzedir. Arıcılık faaliyetleri de bu değişimden fazlasıyla etkilenmektedir. Arılar bitki örtüsü ve sıcaklık değişimlerine karşı oldukça duyarlı canlılardır. Bundan dolayı arıcılık faaliyetleri ve küresel iklim değişiminin Koyulhisar İlçesi özelindeki yansımalarının yakın gelecekte takip edilmesi ve araştırılması önerilebilir.

Araştırmanın yapıldığı alanda arıcılık işleriyle uğraşan ya da çevredeki yerleşim birimlerinde arıcılıkla uğraşan bireylerin bal ormanlarından daha fazla yararlanmalarını sağlamak için bitki çeşitliliğinin devamını sağlamak, temiz su kaynakları oluşturmak ve arılara zarar veren yabanıl hayvanlara karşı tedbirler almak gibi adımlar atılması önerilebilir. Ayrıca ballı bitkilerce zengin floranın olduğu yerlerin bal ormanı sahaları olarak seçilmeli, bu sahaların özellikle bal ve arı sütü verimini arttırıcı yönde hazırlanmalı, saha seçiminde bal üretim sezonu öne çıkarılmalıdır (Güngör, 2018).

Bal ormanlarından yararlanan bireylerin arı ve arıcılık faaliyetleri ile ilgili daha fazla bilgilenmeleri sağlanmalı, onlara eğitimler verilmelidir. Modern arıcılık ve arı ürünleri üretimi hakkında destek imkânları arttırılabilir. Yine Koyulhisar İlçesi'nin bal üretimi için elverişli olması nedeniyle bal haricinde diğer arı ürünleri üretiminin geliştirilmesi ve arttırılması sağlanabilir. Ayrıca bal üretimi için kovan sayısının ve kovan başına düşen verimlinin arttırılması önerilebilir.

Yörenin iklim ve doğal yapısına uygun tıbbi aromatik bitkilerin kullanımı ile arıcılığın geliştirilmesi başta olmak üzere yöre halkına ekonomik katkılar sağlanabilir (Yıldız ve Fakir, 2019).

Araştırma konusuna yönelik gerçekleştirilecek benzer çalışmalar ile ülkemiz ormanlarında potansiyel bal ve diğer arı ürünleri üretim alanları ve ekonomik değerleri belirlenmeli ve bu alanlara ilişkin etkin yönetim planları geliştirilmelidir. Diğer yandan, ülkemizde arı ürünleri ticaretinde az sayıda kurumsal firmaların varlığı, üretilen bal kalitesi ve veriminin düşük olması arı ürünleri satış fiyatı üzerinde etkili mikro değişkenlerdir. İklimsel değişimler, komşu ve rakip bölgelerdeki bal üretim değerleri ile ülkenin ekonomik durumu satış fiyatında etkili makro değişkenlerdir. Arı ürünleri verimini arttırmaya yönelik çalışmalarda bahsedilen mikro ve makro değişkenler dikkate alınmalıdır (Cesur ve Güngör, 2019). Böylelikle ülkemiz ormanlarından sağlanacak bal üretim değerlerinin miktar ve nitelik olarak daha iyi seviyelere çıkabileceği düşünülmektedir.

Sonuç olarak Koyulhisar yöresinde arıcılık yapmaya istekli insanların varlığının olması, halk eğitim merkezinin de arıcılıkla uğraşmak isteyenlere kurs düzenlemesi gibi desteklerin de olması nedeniyle daha fazla önem verilmesi gereken bir alandır. Koyulhisar İlçesi’nde arıcılık faaliyeti yapan kişilerin sosyo-ekonomik 
yapıları geliştirilmelidir. Yöre arıcıları ürünlerinin pazarlanması konusunda yeterli bilgiye sahip olmadıkları için pazarlama kanallarını etkin kullanamamaktadır. Dolayısıyla yöre arı ürünlerinin bölge ve ülke ekonomisine katkısı düşük olmaktadır.

\section{Teşekkür}

$\mathrm{Bu}$ çalışma Sivas Cumhuriyet Üniversitesi Bilimsel Araştırma Projeleri Komisyonu tarafından KMYO-003 Numaralı A-Tipi Bireysel Araştırma Projesi olarak desteklenmiştir. Ayrıca bu çalışma "Ejons 5. International Congress on Mathematics, Engineering, Natural And Medical Sciences” isimli kongrede poster olarak sunulmuştur. Desteklerinden dolayı Sivas Cumhuriyet Üniversitesi'ne teşekkür ederiz. Ayrıca proje süresince desteğini esirgemeyen Ahu KUTLAY'a, arazi çalışmaları sırasında destek olan Mustafa DÜNDAR'a, Osman METLIOĞLU ve Koyulhisar Orman İşletme Müdürlüğü’ne teşekkür ederiz. 


\section{EK 1: Kapalı Uclu Anket Soruları}

Cinsiyet: Yags: $\quad$ Eğitim Düzeyi:

1) Anciluktan yllluk üretim miktanniz ne kadar?
A) $50-100 \mathrm{~kg}$
B) $100-250 \mathrm{~kg}$
C) $250-500 \mathrm{~kg}$
D) $500-1000 \mathrm{~kg}$ E) 1 ton ve üzeri

2) Anlannuza zarar veren hayvanlar nelerdir?
A) Ayz-Domuz
B)Eşek Ans1-Karnca C)An Biti, An Gívesi
D)An Kuşu E)Fare Sıçan, Kurbağa

3) Ancığı hangi amaçlı yapłyorsumuz?
A)Ancilikla ilgilenmiyonm
B)Hobi
C)Ekonomik-Hobi
D)Yan gelir amaçh
E)Ekonomilk

4) Kaç tane kovan saymz bulunmaktadar?
A) $1-25$
B) $25-50$
C) $50-75$
D) $75-100$
E)100 ve üzeri

5) Bal üretimi hariç hangi ancluk ürünleri üretiyorsumuz?
A)Propolis
B)Polen
C) Bal Muma
D)Süzune Bal E)Petel Bal

6) Anciluk ile ilgili problemleriniz neler?
A) Konaklama
B)Verimlilivs
C)Pazarlama
D)Üretim
E)Diğer

7) Ünününüzū pazarladığmız kesimi nereler oluģtunuyor?
A) Yakın Çevre
B)Ilçeler, Kōyler
C) Çevre iller
D)Büyük Șehirler
E)Diğer

8) Ancluk d’şuda bir mesleğiniz (yan geliriniz) var mu?
A)Çiftçi
B) Ormancilik
C)Başka gelir yok
D)Memur
E) İş̧

9) Kowan konaklama yerleriniz nerelerdir?
A)Yakın çevreler
B)Mera
C)Yayla
D)Bal Ormanlan
E) Orman

10) Ancıkla ilgjili hangi eğitimi aldınz?
A)Eğitim almayı dūşūnüyorum
B)Eğitim almadım
C) Geleneksel Ancilik
D)Organik ve Geleneksel Anciluk
E) Organils Anclik

11) Kaç yldar ancilik yapuyorsunuz?
A) $1-12$ ay
B) 1-3 yil
C) $3-5$ yll
D) $5-7$ yl
E)7 ve üzeri

12) Ana anyı nereden temin ediyorsunuz?

A)Eş. Dost(Yakın (̧evre) B)Kendi üretimim C)Diğer Üreticiler D)Tanm Müdürlüğü E)Ticari Üreticiler

13) Ancilukta hangi an urkm tercih ediyorsunuz?
A)Kaflkas+KamiyolMelezi
B)Kamiyol
C)Anadolu
D)Kafkas
E) Bilinmeyen

14) Anlann bakumum kim yapiyor?
A)Kendiniz
B)Eşiniz
C)Komģumuz
D)issçiler
E)Diğer

15) Ancllak ve bal üretimi ile ilgili gerekli bilgiyi hangi kaynaklardan temin ediyorsunuz?
A)Dergi
B)Kitap
C)intemet
D)Televizyon
E)Yakın çevre ve gelenekler 
EK 2: Standart Sorulu Anket Soruları

Cinsiyet: Yaș: Eğitim Dīzeyi:

1) Ancılığı ekonomik amaçlı yapıyorum.
A)Hiçbir zaman
B)Nadiren
C)Bazen
D) Genellikle E)Her zaman

2) Ürünümün pazarlandığı yeri bilinim.
A)Hiçbir zaman
B)Nadiren
C)Bazen
D)Genellikle E)Her zaman

3) Ancılkla ilgili eğitim almayı düģünürüm.
A)Hiçbir zaman
B)Nadiren
C)Bazen
D)Genellikle E)Her zaman

4) Ancılık dışında yan gelire sahibim.
A)Hiçbir zaman
B)Nadiren
C)Bazen
D) Genellikle
E)Her zaman

5) Devletin oluşturduğu bal ormanlarum tercih ederim.
A)Hiçbir zaman
B)Nadiren
C)Bazen
D)Genellikle E)Her zaman

6) Ana anya ihtiyaç duyduğumda nereden temin edeceğimi bilirim.
A)Hiçbir zaman
B)Nadiren
C)Bazen
D)Genellikle E)Her zaman

7) Arılarm bakımın 3. Şahıslara (para karşılığı başkalanna) yaptırıım.
A)Hiçbir zaman
B)Nadiren
C)Bazen
D)Genellikle E)Her zaman

8) Ancılık için devletten destek alırum.
A)Hiçbir zaman
B)Nadiren
C)Bazen
D)Genellikle E)Her zaman

9) Ancılık ve bal üretimi ile ilgili gerekli bilgiyi uzmanlardan alırım.
A)Hiçbir zaman
B)Nadiren
C)Bazen
D)Genellikle E)Her zaman

10) Sertifikalı ancllk yapılmasını destekliyor musunuz?
A)Hiçbir zaman
B)Nadiren
C)Bazen
D)Genellikle E)Her zaman

11) Ancılık için devletten destek alyyor musunuz? (Teşvik, Kredi)
A)Hiçbir zaman
B)Nadiren
C)Bazen
D)Genellikle E)Her zaman 


\section{Kaynaklar}

1. Akyol, A., Cazăg, S.N. (2018). Beekeepers' Expectations and Evaluations for Beekeeping Development. $1^{\text {st }}$ International Symposium on Silvopastoral Systems and Nomadic Societies in Mediterranean Countries, 22-24.10.2018, Isparta, Turkey.

2. Arıcılık Yönetmeliği. (2011). Gıda, Tarım ve Hayvancılık Bakanlığı, Sayı: 28128.

3. Bal Eylem Planı. (2004). Tarım ve Orman Bakanlığı. Antalya İl Tarım ve Orman Müdürlüğü Yayını.

4. Cesur, E., Güngör, E. (2019). Ar1 Ürünleri Ekonomisi Açısından Bandırma Yöresi Orman Kaynaklarının İncelenmesi (Tam Metin). II. Hasat Uluslararası Tarım ve Orman Kongresi, 417-426, ISBN: 978-605-7736-38-3, İzmir.

5. Ekiz, D. (2003). Eğitimde Araştırma Yöntem ve Metotlarına Giriş: Nitel, Nicel ve Eleştirel Kuram Metodolojileri. Anı Yayıncılık. Ankara: 190s.

6. FAO (2015). Food and Agr. Org. Honey Inf . http://www.fao.org (17.11.2015).

7. FAO (2017). Dünya Arıcılık Verileri. https://arastirma.tarimorman.gov.tr (19.04.2020).

8. Gül, A. (2008). Türkiye’de Üretilen Balların Yapısal Özelliklerinin Gıda Güvenliği Bakımından Araştırılması. Doktora Tezi (yayımlanmamış), Mustafa Kemal Üniversitesi, Fen Bilimleri Enstitüsü, Zootekni Anabilim Dalı. Hatay.

9. Güngör, E., Ayhan, A.B. (2016). Bartın Yöresi Orman Kaynaklarının Bal Üretim Potansiyeli ve Ekonomik Değeri. Turkish Journal of Forestry, 17(1), 108-116.

10. Güngör, E. (2018). Determination of Optimum Management Strategy for Honey Production Forest Lands Using A'WOT and Conjoint Analysis: A Case Study in Turkey. Applied Ecology and Environmental Research 16(3):3437-3459. http://www.aloki.hu • ISSN 15891623 (Print) • ISSN 1785 0037 (Online) DOI: http://dx.doi.org/10.15666/aeer/1603_34373459.

11. Kadirhanoğulları, İ.H., Karadaş, K., Külekci, M. (2016). Iğdır İli Arıcılarının Sosyo-Ekonomik Durumu. Uludă̆ Arlcılık Dergisi, 16(1), 2-11.

12. Karadeniz, V. (2010). Koyulhisar'ın Coğrafi Etüdü. Doktora Tezi (yayımlanmamış), Atatürk Üniversitesi, Sosyal Bilimler Enstitüsü, Ortaöğretim Sosyal Alanlar Eğitimi Anabilim Dalı, Erzurum.

13. Karasar, N. (2003). Bilimsel Araştırma Yöntemi. (12. Baskı). Nobel Akademik Yayıncılık. Ankara: $268 \mathrm{~s}$. 14. Koday, S. (2005). Doğu Anadolu Bölgesi’nde Hayvancılık. Atatürk Üniversitesi Yayınları No: 949, FenEdebiyat Fakültesi Yayınları No: 104, Araştırmalar Serisi No: 74, Erzurum.

15. Koday, Z., Karadağ, H. (2019). Türkiye’de Bal Ormanlarının Gelişimi ve Bölgesel Dağılımı (20072018). Atatürk Üniversitesi Sosyal Bilimler Enstitüsü Dergisi, 23(3), 1227-1242.

16. Koyulhisar İlçe Tarım Müdürlüğü, (2014). (Veriler arşiv kaynaklarından derlenmiştir).

17. Koyulhisar İlçe Tarım Müdürlüğü, (2015). (Veriler arşiv kaynaklarından derlenmiştir).

18. Köseman, A., Şeker, İ., Karlıdă̆, S., Güler, H. (2016). Arıcılık Faaliyetleri - I, Arı Yetiştiricilerinin Sosyo-Demografik Özellikleri, Problemleri ve Beklentileri ile Arıcılıkta İdari ve İktisadi Mevcut Uygulamalar. Kocatepe Veterinary Journal, 9(4), 308-321.

19. Krell, R. (1996). Value-Added Products from Beekeeping. FAO Agricultural Services Bulletin. No:124. Rome, Italy.

20. OGM, Bal Ormanı Eylem Planı. (2013). Tarım ve Orman Bakanlığı, Orman Genel Müdürlüğü. Ankara, $136 \mathrm{~s}$.

21. Önal, P., Bekiroğlu, S. (2011). Orman Köylerinde ORKÖY Tarafından Gerçekleştirilen Köy Kalkındırma Projelerinin Uygulama Sonuçlarının Araştırılması (Şile-İstanbul). Journal of the Faculty of Forestry Istanbul University, 61(2), 53-66.

22. Pirim, L., Çan, M.F., Sönmez, M.M. (2009). Bingöl Arıcılık Raporu, Fırat Kalkınma Ajansı, Bingöl, 38 s.

23. Söğüt, B., Şeviş, H.E., Karakaya, E., İnci, H. (2019). Arıcılık İşletmelerinde Mevcut Durum, Temel Sorunlar ve Çözüm Önerileri Üzerine Bir Araştırma (Bingöl İli Örneği). Uludă̆ Arıcılık Dergisi, 19(1), 50-60.

24. Tarım Ürünleri Piyasaları (TÜP). (2020). Arıcılık, Tarımsal Ekonomi ve Politika Geliştirme Enstitüsü, $4 \mathrm{~s}$.

25. TÜİK (2020). 2019 Yılı Türkiye Arıcılık İstatistikleri. 
26. Yıldız, S., Fakir, H. (2019). Bal Üretim Ormanları İçin Potansiyel Bitki Türleri: Isparta Keçiborlu Güneykent Bal Üretim Ormanı Örneği. Bilge International Journal of Science and Technology Research, 3(2), 213-222. 